\title{
PEMAKAIAN KAEDAH FIQH TERHADAP ISU PENYERUPAAN (AL-TASYABBUH) DALAM KONTEKS MASYARAKAT MAJMUK DI MALAYSIA*
}

\section{Using the Islamic Legal Maxim in Respect of the Imitation (al-Tasyabbuh) Issue among the Muslim Society in Malaysia}

\author{
Mohd Anuar Ramli ** \\ Paizah Hj Ismail *** \\ Ahmad Badri Abdullah****
}

\begin{abstract}
This research focuses on some Islamic legal maxims (al-Qawa'id al-Fiqhiyyah) pertaining to the issue of prohibited imitation (al-tasyabbuh) among Muslims of non-Muslims. Several issues that relate to the interaction process between Muslim and nonMuslim societies in the contemporary local context are discussed in this paper, such as issues concerning costumes, celebrations, and politics. In the process, in analysing these issues, the Islamic legal maxims are being applied, which are formulas concluded by fiqh scholars by referring to Qur'anic texts and prophetic traditions, as well as the jurisprudential
\end{abstract}

Artikel ini adalah sebahagian daripada dapatan Projek RG40812HNE.

** Pensyarah, Jabatan Fiqh dan Usul, Akademi Pengajian Islam, Universiti Malaya, mohdanuar@um.edu.my

*** Konsultan, Jabatan Fiqh dan Usul, Akademi Pengajian Islam, Universiti Malaya, paizah_ismail@yahoo.com

**** Pembantu Penyelidik, Jabatan Fiqh dan Usul, Akademi Pengajian Islam, Universiti Malaya. 
conclusions from classical works that discussed altasyabbuh intensively. The results from the research showed that these maxims are able to become general rules for classifying any act of interaction between Muslims and non-Muslims as a practice of prohibited imitation (al-tasyabbuh).

Keywords: al-Tasyabbuh (Imitation), Legal Maxims, Muslim Society, Plural Society, Local and Contemporary

\section{PENGENALAN}

Al-Tasyabbuh merupakan fenomena sosial yang dinamik. Ia berkembang seiring dengan perubahan sosio budaya masyarakat. Keadaan ini boleh ditelusuri dalam sejarah kebudayaan Melayu di Malaysia. Misalnya, zaman sebelum merdeka, isu al-tasyabbuh dikaitkan dengan warisan tinggalan zaman Hindu-Buddha yang diamalkan dalam masyarakat Melayu seperti adat istiadat dalam menyambut kelahiran bayi serta dalam adat perkahwinan seperti berinai dan bersanding. Sedangkan pasca kemerdekaan pula, ia dikaitkan dengan amalan yang menyerupai budaya Barat seperti cara berpakaian dan gaya hidup.

Selain itu, dalam interaksi budaya antara masyarakat Melayu dengan masyarakat luar, gejala al-tasyabbuh turut berlaku. Misalnya, zaman sebelum merdeka, kewujudan masyarakat majmuk begitu ketara dengan setiap kaum mempunyai identiti yang eksklusif dan tersendiri. Jurang budaya antara kaum menjadi luas kerana interaksi begitu minimum. Masing-masing kaum ingin mempertahankan jati diri. Namun kini, pasca merdeka, jurang budaya makin mengecil. Setiap kaum dapat menerima dan mengamalkan cara hidup kaum lain tanpa batas demi mewujudkan perpaduan Negara. ${ }^{1}$

Masyarakat Islam hari ini dapat menerima budaya kaum lain. Mereka tidak rasa bersalah memakai pakaian kaum lain, pottu dan pakaian Santa Clause, meraikan perkahwinan ala-Barat, menyertai perarakan membawa lilin dan seumpamanya. Selain

Mohd Anuar Ramli \& Mohammad Aizat Jamaludin, "“Uruf Majmuk: Konsep Dan Amalannya Dalam Masyarakat Majmuk Di Malaysia”, Jurnal Fiqh, no. 8 (2011): 45-64. 
itu, dampak globalisasi juga menyumbang kepada amalan yang menyerupai kaum lain. Budaya Barat diimport ke masyarakat Islam berdasarkan promosi yang kuat melalui medium media massa sama ada elektronik mahupun cetak. Dengan itu golongan muda dengan mudah terdedah, terpesona dan terpengaruh dengan budaya Barat. Budaya Barat menjadi ikutan dan tren semasa dalam kalangan remaja. Selari dengan itu, berlaku penyerupaan dalam kalangan orang Islam terhadap budaya Barat.

Fenomena tersebut dianggap sebagai biasa oleh masyarakat hari ini, sedangkan dalam perbincangan fiqh, ia mempunyai implikasi hukum yang tertentu. Ini kerana tiap amalan atau tradisi agama dan budaya kaum bukan Islam sama ada timur atau barat tidak lahir dari ruangan kosong tanpa makna dan nilai, sebaliknya ia dipenuhi dengan muatan falsafah keagamaan dan kepercayaan khusus sebagai medium legitimasi amalan tersebut. Jika tidak, ia akan ditinggalkan serta tidak diamalkan oleh masyarakat, malah tidak diwarisi dari satu generasi ke satu generasi yang lain.

Sehubungan dengan itu, dalam menilai amalan-amalan tersebut, para ulama telah menggariskan beberapa kaedah fiqh yang khusus. Kaedah-kaedah fiqh (qawā'id al-fiqhiyyah) merupakan mekanisme penetapan hukum yang penting dalam disiplin fiqh. Ia adalah kesimpulan-kesimpulan umum yang dibuat hasil daripada kesimpulan yang bersifat induktif terhadap hukum-hakam fiqh yang telah dibahaskan dalam sebarang tema permasalahan tertentu. ${ }^{2}$ Melalui formula-formula umum ini, para fuqaha dapat membuat kesimpulan-kesimpulan hukum baharu yang tidak pernah ditetapkan sebelum ini. Dengan bantuan kaedah fiqh, disiplin hukum Islam mampu berinteraksi dengan perubahan yang berlaku dalam sesebuah masyarakat kesan daripada perubahan masa, lokasi, adat dan suasana.

Berpandukan kaedah-kaedah fiqh ini, penetapan hukum dapat dilakukan dengan lebih tepat bagi mengklasifikasikan sesuatu perbuatan itu sebagai penyerupaan (al-tasyabbuh) terhadap orang bukan Islam yang dilarang ataupun tidak.

2 Muḥammad Bakr Ismā‘̄îl, al-Qawā'id al-Fiqhiyyah: Bayn al-Aṣālah wa al-Tawjīh (Qāhirah: Dār al-Manār, 1997), 6. 


\section{KONSEP AL-TASYABBUH}

Secara literalnya, perkataan al-tasyabbuh berasal dari bahasa Arab, akar katanya sya-ba-ha. Ia merujuk kepada penyerupaan kepada sesuatu, persamaan warna dan sifat. Disebut juga syibh, syabah, dan syabih. ${ }^{3}$ Menurut Ibn Manz̧ūr, suatu objek itu menyerupai atau menyamai dengan sesuatu yang lain. ${ }^{4}$

Dari segi istilah, menurut Imam al-Ghazālī, al-tasyabbuh adalah ungkapan yang menunjukkan usaha manusia untuk menyerupakan dirinya dengan sesuatu yang diinginkan dirinya serupa dengan sesuatu tersebut sama ada dalam hal tingkah laku, pakaian, atau sifat-sifatnya. Jadi al-tasyabbuh adalah ungkapan tentang tingkah yang diinginkan dan dilakukannya. ${ }^{5}$

Al-Luwayhiq menjelaskan al-tasyabbuh sebagai seseorang yang membebani diri untuk menyerupai selainnya berkenaan dengan segala sifat atau sebagainya. Perkataan "membebani diri" menunjukkan bahawa maksud berkeinginan dan sengaja. Dengan demikian tidak termasuklah segala sesuatu yang tidak sengaja, seperti serupanya seorang lelaki dengan wanita dalam tingkahlaku dan suara kerana tabiat yang tercipta tanpa adanya niat dan keinginan. ${ }^{6}$

Begitu juga apabila seseorang Muslim menyerupai bukan Islam dalam segala bentuk dan sifatnya, sama ada dari sudut kepercayaan, amalan, kebudayaan atau tingkah laku. ${ }^{7}$ Ini kerana menyerupai mereka bererti menunjukkan rasa cinta dan cenderung kepada mereka. ${ }^{8}$

3 Aḥmad Fāris, Mu jam Maqāyı̄s al-Lughah, (tahqiq) 'Abd al-Salām Hārūn. (Bayrūt: Dār al-Jayl, 1411H), 3 : 243.

4 Ibn Manẓūr, Lisān al- 'Arab (Bayrūt: Dār Iḥyā' al-Turāth al- 'Arabī, 1999), $7: 24$.

5 Jamīl Ḥabīb al-Luwayḥiq, al-Tasyabbuh al-Manhi 'anhu fì al-Fiqh al-Islāmì (Makkah: Jāmi'ah Umm al-Qurā \& Wizārah Ta'līm 'Alī, 1417H), 20.

6 Ibid.

7 Șāliḥ Fawzān, 'Aqīdah Tawhīd (Riyāḍ: Dār al-Qāsim, t. t.), 185.

8 'Abd Allāh 'Abd al-'Azīz al-Tuwayjirī, al-Bida' al-Hawliyah, (terj.) Munirul Abidin (Jakarta: Darul Falah, 2000), 118. 
Perkara ini juga turut ditegaskan oleh Barqa'an dalam beliau memberi takrifan terhadap al-tasyabbuh. Beliau menyatakan bahawa takrifan yang lebih tepat mengenai 'al-tasyabbuh' adalah:

Penyerupaan orang Muslim terhadap orang kafir pada sesuatu perkara yang tidak termasuk dalam kategori maslahah yang muktabar. ${ }^{9}$

Keunikan yang terdapat di dalam takrif ini adalah pendekatan untuk mengeluarkan perkara-perkara yang merupakan 'mașlahah al-mu'tabarah' iaitu kemaslahatan yang diiktiraf oleh nasnas Syarak daripada kategori al-tasyabbuh yang dilarang atau diharamkan tadi. Ini bertepatan dengan konsep al-tasyabbuh pada perkara yang mendatangkan manfaat. Oleh yang demikian, setiap perkara sama ada dari segi ilmu, teknologi, kemahiran atau penemuan-penemuan saintifik baharu yang bermanfaat dan merupakan maslahah yang diiktiraf oleh Syarak mengenai manfaatnya, maka ia terkeluar daripada kategori al-tasyabbuh yang dilarang walaupun ia berasal daripada orang bukan Islam. Prinsip ini diambil daripada peristiwa Rasulullah SAW mengaplikasikan teknologi mengorek parit ketika perang Khandak yang pada hakikatnya berasal daripada amalan orang bukan Islam di Parsi.

\section{ASAS LARANGAN $A L-T A S Y A B B U H$}

Terdapat banyak dalil Syarak khususnya daripada hadis Nabi SAW yang menyentuh secara langsung atau tidak langsung mengenai perbuatan al-tasyabbuh ini. Antara hadis yang utama membicarakan hal ini ialah yang diriwayatkan daripada 'Abd Allah Ibn 'Amru r.a., bahawa Rasulullah SAW bersabda:

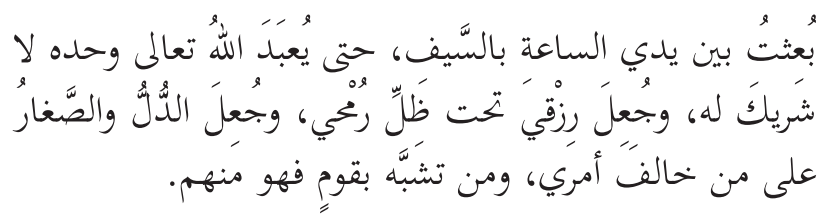

\footnotetext{
9 Asyraf bin 'A bd al-Hamīd Barqa'an, "Mazāanir al-Tasyabbuh fī al"Așr al-Hadīth wa Atharuhā 'ala al-Muslimīn" (Disertasi Master, Universiti Umm al-Qura, 1417H), 17.
} 
Aku diutuskan ketika di hadapanku hari kiamat, dengan pedang sehingga beribadah kepada Allah semata-mata dan tidak mensyirikkanNya, dijadikan rezekiku di bawah bayangan pedang, dan dijadikan hina dan kecil barangsiapayang menyalahiurusanku, dan barangsiapa yang menyerupai sesuatu kaum dia adalah dari kalangan mereka. ${ }^{10}$

Selain itu, Nabi SAW dengan tegas memerintahkan orang Islam untuk tampil berbeza dengan penampilan orang-orang bukan Islam dalam semua perkara hinggalah dalam penampilan fizikal. Antaranya sabda Rasulullah SAW dalam menyuruh orang Islam berbeza dengan orang musyrik: ${ }^{11}$

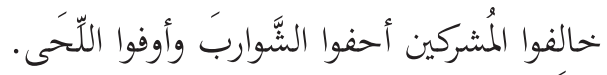

Berbezalah dengan orang musyrikin. Potonglah misai dan biarkanlah janggut.

Sabda Nabi SAW dalam menyuruh orang Islam berbeza dengan orang Yahudi:

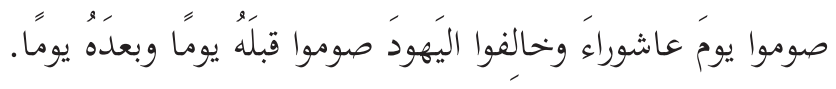

Berpuasalah kamu 10 Muharram dan berbezalah dengan orang Yahudi. Puasalah kamu sebelum dan selepasnya sehari.

Sabda Nabi SAW dalam menyuruh orang Islam berbeza dengan orang Majusi: ${ }^{12}$

10 Al-Bukhārī, Șahīh al-Bukhārī, Kitāb al-Jihād, Bāb Mā Qīla fī alRamah, lihat Ibn Hajr al-'Asqalān̄̄, Fath al-Bārī bi Syarh Ṣaḥịh alBukhārī (Qāhirah: Maṭba'ah al-Salafiyyah, 1960), 6 : 98; Muḥammad Ibn Ab̄̄ Syaybah, al-Mușannif, Mukhtār al-Nadwī (tahqiq) (Hind: al-Dār al-Salafiyyah, t. t.), 12 : 351, no. hadis: 13062; 'Abd bin Humayd, al-Muntakhab min Musnad, Muștafa al-'Adwī (tahqiq), (Makkah: Maktabah Ibn Hajr, 1408H), 2: 50-51.

11 Muslim al-Hajjāj al-Qusyayrī, Șaḥ̄h Muslim (Bayrūt: Dār Iḥyā' alKitāb al-'Arabiyyah, t. t.).

12 Sahīh Muslim, no. hadis: 260. 


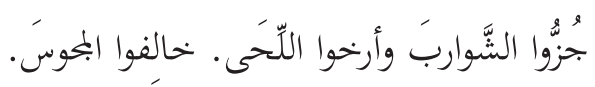

Potonglah misai dan biarkanlah janggut. Berbezalah dengan orang Majusi.

Hadis-hadis tersebut menunjukkan larangan yang tegas tentang al-tasyabbuh dengan orang bukan Islam sama ada mereka dari kalangan penganut agama samawi seperti Yahudi, ataupun agama budaya, penyembah api dan berhala seperti musyrik dan Majusi.

\section{APLIKASI KAEDAH FIQH (QAW $\bar{A} \cdot I D A L-F I Q H I Y Y A H)$ DALAM PENENTUAN HUKUM $A L-T A S Y A B B U H$}

Secara asasnya, terdapat beberapa kaedah fiqh (Qawā'id alFiqhiyyah) yang telah digariskan oleh para ulama yang dapat menjadi indikator utama bagi mengklasifikasikan sesebuah amalan sebagai al-tasyabbuh. Antara kaedah tersebut adalah:

i.

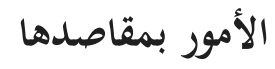

Sesuatu perkara bergantung kepada objektif ia dilakukan ${ }^{13}$

Kaedah ini membawa maksud bahawa sesuatu perbuatan tidak dikira sebagai al-tasyabbuh selagi mana tidak disertakan dengan niat kerana al-tasyabbuh terjadi apabila pelaku perbuatan tersebut bertujuan untuk menyerupai pihak yang ingin ditirunya. ${ }^{14}$ Bagi penyerupaan secara zahir semata-mata tidak dikira sebagai altasyabbuh walaupun ia tetap diistilahkan sebagai al-tasyabbuh oleh kebanyakan para fuqaha. ${ }^{15}$ Ini merujuk kepada beberapa hadis yang menunjukkan setiap amalan adalah bergantung kepada niat para pelakunya. Ibn 'Ābidīn dalam memberi komentar terhadap hadis berhubung al-tasyabbuh, beliau menyatakan bahawa:

13 Muḥammad Șidq⿳亠丷 Ibn Aḥmad al-Burnū, Mawsū'ah al-Qawā'id al-Fiqhiyyah: Jam'wa Tartīb wa Bayān (Bayrūt: Mu'assasah alRisālah, t. t.), 120.

14 Luwayhiq, al-Tasyabbuh al-Manhi 'anhu, 72.

15 Para fuqaha kebanyakannya membahaskan mengenai larangan bagi amalan-amalan ini merujuk kepada kaedah sadd al-dharī'ah. 
Ia bermaksud jika ianya diniatkan, maka pada hakikatnya penyerupaan terhadap mereka tidak dimakruhkan pada setiap perkara bahkan hanya pada perkara-perkara yang dikeji, dan apa yang diniatkan untuk penyerupaan. ${ }^{16}$

Dalil yang menyokong kaedah ini adalah hadis Rasulullah SAW mengenai niat setiap perbuatan. Riwayat daripada Saydina 'Umar al-Khatțāb r.a. bahawa Rasulullah SAW bersabda:

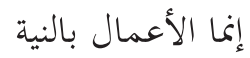

"Sesungguhnya setiap perkara (perbuatan) adalah pada yang diniatkan padanya." 17

Ini merupakan kaedah asas bagi mengklasifikasikan suatu perbuatan itu al-tasyabbuh ataupun tidak. Tetapi ia tertakluk kepada perbuatan tersebut bukanlah bersifat amalan khusus keagamaan dan adat orang bukan Islam.

Dalam konteks masyarakat Malaysia, kaedah ini dapat diaplikasi dalam beberapa kes. Misalnya seseorang memakai pakaian berwarna hitam tanpa niat berkabung kematian orang bukan Islam, ia tidak dianggap sebagai al-tasyabbuh. Begitu juga dalam isu memakai tudung yang menyerupai rahib Kristian Ortodoks. Ia tidak dianggap sebagai al-tasyabbuh sekiranya tidak disertai dengan niat dan dalam masa yang sama tetap menutup aurat seperti yang digariskan oleh Syariat Islam. Selain itu, termasuk dalam kaedah ini juga adalah amalan pemasangan pelita dan lampu semasa musim perayaan Aidil Fitri. Semua amalan ini berkait dengan niat seseorang ketika mengamalkannya sama ada menyerupai dengan niat atau tidak.

Selain itu, setiap yang diamalkan oleh orang bukan Islam yang terdiri daripada amalan ibadah, yang dapat memberi implikasi

16 Ibn 'Ābidīn, Hạsyiyah Ibn 'Ābidīn, 'Ādil 'Abd al-Mawjūd (tahqiq), (Bayrūt: Dār al-Kutub al-'Ilmiyyah, 1415H), 2 : 384.

17 Al-Bukhārī, Șaḥ̄h al-Bukhārī, Kitāb Bad'i al-Waḥyi, Bāb Kayfa Bad'i al-Waḥyi ilā Rasūlillāh, no. hadis: 1; Muslim, Șạ̄h Muslim. Kitāb al-Imārah, Bāb Qawluhu (Innamā A'māl bi al-Niyyāt), no. hadis: 1907. 
menjadi kafir atau berbentuk maksiat jika dilakukan dengan niat, tidak wajar dizahirkan oleh Muslim, walaupun dia tidak meniatkannya dengan niat yang sama dengan golongan bukan Islam, sebagai langkah pencegahan. ${ }^{18}$

Ia bermaksud bahawa setiap perbuatan atau pakaian yang menyerupai orang bukan Islam secara zahirnya, iaitu sama ada dalam bentuk peribadatan atau adat yang khusus bagi mereka, maka kesemuanya dilarang (haram ataupun makruh) walaupun ianya tidak melibatkan sebarang niat untuk menyerupai golongan kafir tersebut. Bahkan biasanya kebanyakan perbuatan ini dilakukan tanpa diniatkan secara khusus untuk menyerupai orang bukan Islam, misalnya membiarkan rambut beruban tanpa menginaikannya seperti diperintahkan oleh Rasulullah SAW. ${ }^{19}$

Ibn al-Qayyim al-Jawziyyah dalam Ahkām Ahl al-Dhimmah menyatakan hikmah dalam sikap membezakan diri dengan orang kafir yang dapat menyokong kaedah ini, iaitu: ${ }^{20}$

Demi mencapai perbezaan yang menyeluruh (dengan orang bukan Islam), dan tidak menyerupai mereka dalam penampilan luaran, dan melaluinya dapat mengelakkan daripada penyerupaan dari aspek batin. Ini kerana penyerupaan dalam salah satu dari aspek berkenaan akan mengundang kepada penyerupaan dalam aspek yang selainnya. Ini merupakan hal diketahui secara pemerhatian. Tidaklah dimaksudkan dengan perubahan dan perbezaan dalam aspek pakaian dan selainnya hanya untuk membezakan orang kafir dan Muslim semata-mata, bahkan ianya dibina atas beberapa objektif lain. Antara objektif yang utama ialah bagi meninggalkan segala faktor yang dapat mengakibatkan penyetujuan dan penyerupaan dengan mereka secara batin. Nabi SAW mengajarkan kepada umatnya untuk meninggalkan

18 Ibn Taymiyyah, Iqtiḍā' al-Ṣirāt al-Mustaqīm, Nāṣir bin 'Abd alKarīm (tahqiq) (Riyāḍ: Maktabah al-Rusyd, t. t.), 1 : 192.

19 Rasyīd Riḍā, Fatāwā al-Imām Muhammad Rasȳ̄d Riḍā, Șalāḥ alDīn Munjid (tahqiq) (Bayrūt: Dār Kitāb al-Jadīd, 1426H), 3 : 962.

20 Ibn al-Qayyim al-Jawziyyah, Ahkām Ahl al-Dhimmah, Șubḥī Șālị̣ (tahqiq) (Bayrūt: Dār al-'Ilm al-Malāyīn, 1983), 2 : 747. 
penyerupaan dengan orang bukan Islam dalam apa jua cara dengan bersabda: 'Berbezanya ajaran kami dengan ajaran musyrikin'. ${ }^{21}$

Dalil yang menyokong kenyataan ini adalah ayat al-Quran dan hadis yang berbentuk larangan pencegahan (sadd al-dhari' 'ah) terhadap sebarang perbuatan menyerupai perbuatan atau sifat yang khusus bagi orang bukan Islam. Ibn al-Qayyim al-Jawziyyah menyenaraikan sebanyak 99 dalil yang menyentuh mengenai persoalan berkenaan. ${ }^{22}$ Antaranya ialah:

a. Ayat al-Quran, surah al-Baqarah ayat 104, menyatakan larangan menyerupai orang bukan Islam iaitu:

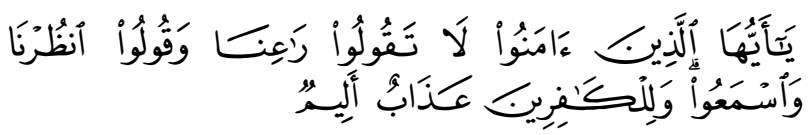

Wahai orang-orang yang beriman! Janganlah kamu mengatakan: «ra'ina», (ketika kamu berkata-kata dengan Nabi Muhammad), sebaliknya katakanlah: «unzurna», dan dengarlah kamu (segala perintah dengan sebulat hati menerimanya); dan (ingatlah, bahawa) orang-orang kafir itu akan beroleh azab seksa yang tidak terperi sakitnya.

b. Daripada 'Aisyah r.ha. beliau berkata:

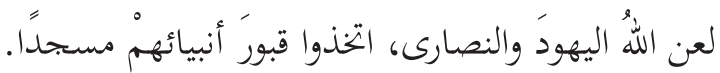

Rasulullah SAW bersabda: Allah melaknati kaum Yahudi dan Nasrani, mereka menjadikan kuburkubur Nabi-nabi mereka sebagai masjid. ${ }^{23}$

Al-Bukhārī, Șaḥīh al-Bukhārī, no. hadis: 1600.

22 Ibn al-Qayyim al-Jawziyyah, I'lām al-Muwaqi'in 'an Rabb al'Ālamīn, Țahā 'Abd al-Ra'ūf (tahqiq) (Bayrūt: Dār al-'Ilm alMalāyīn, 1983), 2 : 137 -159.

23 Al-Bukhārī, Șaḥ̄ḥ al-Bukhārī, no. hadis: 1330. 
Kaedah ini diperkuatkan lagi dengan kaedah lain, iaitu: ${ }^{24}$

$$
\text { الرضا بالكفر فهو كفر. }
$$

Begitu juga dengan kaedah:25

$$
\text { الرضا بالمعصية معصية. }
$$

\section{Meredhai maksiat adalah maksiat.}

Berasaskan kaedah tersebut, perbuatan yang meredhai kekufuran orang Islam hukumnya adalah kufur, begitu juga meredhai perbuatan berbentuk maksiat, hukumnya juga adalah maksiat. Dalam perbincangan fiqh, terdapat beberapa isu yang telah diaplikasikan oleh ulama pelbagai mazhab yang kebanyakannya tidak didasari oleh sebarang nas yang khusus. Antara hukumhukum tersebut ialah larangan bersolat di hadapan gambar haiwan yang bernyawa, ${ }^{26}$ larangan bersolat di hadapan batu, ${ }^{27}$ larangan bersolat di hadapan api, dan larangan untuk melewatkan perlaksanaan solat maghrib sehingga munculnya bintang-bintang di langit. ${ }^{28}$ Semua amalan ini dilarang bagi mengelak berlakunya al-tasyabbuh.

Dalam konteks masyarakat Malaysia, kaedah ini dapat diaplikasi dalam larangan amalan kongsi raya antara orang Islam dengan bukan Islam seperti perkongsian hari raya Deepavali dengan Aidil Fitri (Deepa-Raya) dan perayaan Gong Xi Fa Chai dengan Aidil Fitri (Gong Xi-Raya), penyertaan orang Islam dalam

24 Muhammad 'Abd al-Raḥmān b. 'Abd al-Rahịim al-Mubārakfūrī, Tuhfah al-Ahwādhī (Bayrūt: Dār al-Kutub al-'Ilmiyyah, t. t.), 8 : 418; Muḥammad b. Aḥmad al-Qurțub̄i, Tafsīr al-Qurțubī (Qāhirah: Dār al-Sya'b, 1372), 5 : 418.

25 Ibid.

26 Syams al-Dīn al-Zarkasȳ̄, al-Mabsūṭ (Bayrūt: Dār al-Ma'rifah, $1331 \mathrm{H}), 1: 210$.

27 Imām Mālik, al-Mudawwanah, Sahnūn \& Ibn al-Qāsim (Syarḥ) (Qāhirah: Maṭba’ah al-Sa‘ādah, t. t.), $3: 88$.

28 Al-Kāsān̄̄, Badā'i ‘ al-Șanā 'i 'fì Tartīb al-Syarā'i', 'Alī Muhammad Ma'wid \& 'Ādil Aḥmad (tahqiq) (Bayrūt: Dār al-Kutub al-'Ilmiyyah, t. t.), $1: 126$. 
perarakan candle light vigil, mengalungkan bunga di gambar sebagai simbolik kematian, penyertaan orang Islam dalam perarakan Thaipusam, pesta Songkran, pesta Ponggal, Yoga dan amalan Feng Shui. Semua amalan ini mempunyai hubung kait yang rapat dengan amalan keagamaan dan adat orang bukan Islam. Ini kerana ia lahir daripada kepercayaan tertentu dalam agama mereka (agama budaya) dan menjadi sebahagian amalan keagamaan dan kepercayaan. Sekiranya dilakukan dengan niat, ia memberi implikasi hukum dan boleh menyebabkan tergelincirnya akidah seseorang lantaran keredhaannya.

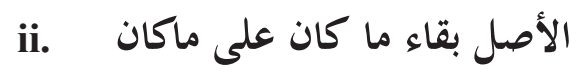

Sesuatu itu adalah kekal seperti asalnya. ${ }^{29}$

Kaedah ini dapat diaplikasikan dalam isu sesuatu perbuatan itu tidak dianggap sebagai al-tasyabbuh melainkan perkara yang dikhususkan kepada mereka dari segi amalan agama atau adat. Ini bermakna, sekiranya perbuatan itu tidak khusus kepada amalan keagamaan dan adat orang bukan Islam, ia kekal boleh dilakukan. Tidak wajar bagi orang Islam menyerupai orang bukan Islam pada perkara-perkara yang khusus bagi mereka sama ada dalam aspek keagamaan mahupun dalam amalan adat kebiasaan mereka. Manakala bagi perbuatan yang dilakukan secara bersama antara orang Islam dan bukan Islam, tidak timbul isu al-tasyabbuh padanya.

Terdapat banyak dalil Syarak yang menyentuh perkara ini secara langsung ataupun tidak langsung. Antaranya ialah hadishadis yang menyatakan larangan memakai pakaian-pakaian yang khusus bagi orang bukan Islam pada konteks tertentu. Antaranya Rasulullah SAW melarang orang Islam untuk memakai baju yang direndam dalam air buah kesumba ( 'asfar). 'Abd Allāh bin 'Amrū al-'Āșṣ menyatakan:

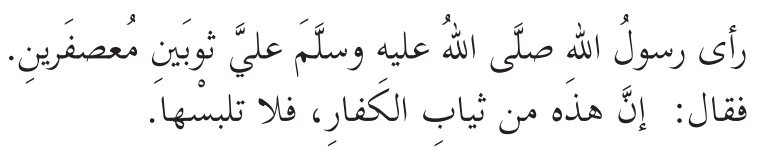

29 Al-Burnū, Mawsū'ah al-Qawā'id al-Fiqhiyyah, 103. 
Pemakaian Kaedah Fiqh Terhadap Isu Penyerupaan (al-Tasyabbuh) dalam Konteks Masyarakat Majmuk di Malaysia

"Nabi SAW melihatku ketika aku sedang mengenakan dua pakaian yang direndam dengan bunga kesumba (mu'asfar), maka Baginda SAW bersabda: 'Sesungguhnya ini adalah pakaian orang kafir, janganlah engkau memakainya." ${ }^{30}$

Antara hukum fiqh di bawah kaedah ini adalah beberapa fatwa daripada ulama pada kurun awal perkembangan Islam yang menyentuh mengenai larangan terhadap beberapa fesyen pakaian yang dianggap sebagai khusus untuk orang bukan Islam pada waktu tersebut. Antaranya ialah:

a) Para fuqaha pada awal kurun ke-8 Hijrah menyatakan bahawa pemakaian serban yang berwarna biru atau kelabu adalah haram disebabkan ia adalah syi ' $\bar{a} r$ bagi orang bukan Islam pada waktu tersebut. ${ }^{31}$

b) Para fuqaha juga melarang masyarakat Muslim daripada sebarang penyertaan dalam perayaan orang bukan Islam. Al-Dhahabī menyatakan:

"Jika terdapat perayaan bagi Nasrani dan Yahudi, yang dikhususkan kepada mereka, maka tidak wajar bagi Muslim menyertai mereka itu untuk menyambutnya, sepertimana tidak wajar menyertai mereka pada agama dan kiblat mereka." ${ }^{32}$

Dalam konteks Malaysia, kaedah ini dapat diaplikasi dalam pengharusan amalan sambutan rumah terbuka dan sambutan tahun baharu. Ini kerana ia bukan amalan yang khusus bagi agama atau adat kaum tertentu disebabkan ia dianjurkan di peringkat nasional. Ia bukanlah amalan keagamaan atau adat orang bukan Islam

\footnotetext{
30 Muslim, Saḥ̄ḥ Muslim, no. hadis: 2077.

31 Manșūr b. Yūnus b. Idrīs al-Bāhūtī, Kasysyāf al-Qinā ‘ 'an Matn alIqnā', (Bayrūt: 'Alam al-Kutub, t. t.), 3: 328.

32 Al-Dhahab̄̄, Tasybīh al-Khașīs li Ahl al-Khamīs fì Radd al-Tasyabbuh bi al-Musyrikīn, Muhammad Ḥassan Ibn Muḥammad Ḥassan Ismā'īl (tahqiq) (Bayrūt: Dār al-Kitāb al-Islāmī, 2002).
} 
secara khusus. Namun isu yang timbul adalah pelaksanaannya yang melibat elemen yang dilarang atau tidak.

\section{iii. إذا زال المانع عاد الممنوع \\ Apabila sesuatu larangan hilang elemen yang dilarang padanya, maka ia kembali harus. ${ }^{33}$}

Kaedah ini selari dengan pandangan sesuatu yang tidak lagi menjadi syiar orang kafir, boleh dilaksanakan selagimana tidak melibatkan sesuatu yang haram secara khusus. Ia bermaksud harus melakukan sebarang amalan atau memakai pakaian yang berasal daripada orang bukan Islam, namun tidak lagi menjadi sesuatu yang khusus bagi mereka setelah berlalunya suatu jangka masa yang tertentu disebabkan halangan telah tiada. Walau bagaimanapun, amalan yang terangkum di bawah kaedah ini hanyalah amalanamalan yang berbentuk adat, manakala amalan ibadah keagamaan sentiasa bersifat khusus kepada penganut agama tertentu dalam apa bentuk sekalipun.

Sifat kekhususan sesuatu amalan ini mungkin hilang apabila sesuatu perbuatan telah tersebar luas sehingga diamalkan oleh segenap lapisan masyarakat. Oleh yang demikian, perlaksanaan amalan sedemikian tidak lagi dianggap sebagai bentuk altasyabbuh yang dilarang oleh agama. Melainkan perbuatan tersebut adalah haram secara tersendiri seperti haramnya perbuatan memakai sutera bagi lelaki.

Terdapat beberapa hukum fiqh yang ditetapkan oleh ulama yang termasuk di bawah kategori kaedah ini, antaranya adalah:

Jawapan Ibn Hiajar al-'Asqalān̄̄ terhadap dakwaan bahawa pemakaian țayālisah ${ }^{34}$ adalah dilarang berikutan hadis yang menyatakan ianya adalah pakaian Yahudi. Daripada Anas bin Mālik r.a., Rasulullah SAW bersabda:

33 'Alī Aḥmad al-Nadwī, al-Qawā'id al-Fiqhiyyah (Damsyiq: Dār alQalam, c. 2, 1991), 352.

34 Dalam al-Musnad, Imam Ahmad bin Hanbal menghuraikan bahawa țayālisah adalah mahkota atau perhiasan di atas kepala. 


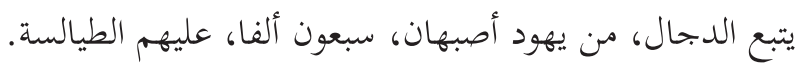

Diikuti dajjal daripada Yahudi Isfahan, tujuh puluh ribu (jumlah mereka) dengan memakai altayalisah. ${ }^{35}$

Ibn Hajar menyatakan bahawa:

Sesungguhnya wajar untuk berdalilkan kisah yahudi tersebut pada masa tayalisah itu merupakan syi ar bagi mereka, dan terangkat perkara itu pada masa kini dan ianya kini termasuk dalam perkara yang diamalkan secara am dan harus. ${ }^{36}$

Selain itu, terdapat beberapa perkara yang perlu diberi perhatian dalam kaedah ini. Penilaian terhadap kekhususan sesuatu perbuatan pada sesuatu kaum atau golongan adalah berdasarkan 'urf setempat. Begitu juga penilaian terhadap hilangnya kekhususan sifat atau perbuatan berkenaan.

Dalam konteks masyarakat Malaysia hari ini, kaedah ini dapat diaplikasi dalam keharusan memakai pakaian orang bukan Islam seperti memakai kot, tali leher, seluar jeans dan topi (cap). Ini disebabkan ianya telah diterima secara global dan tidak lagi menjadi pakaian eksklusif orang bukan Islam. Begitu juga dibolehkan sambutan hari lahir, hari guru, hari pekerja dan seumpamanya kerana ia bukan lagi amalan orang bukan Islam dan syiar mereka.

\section{iv. شرع من قبلنا شرع لنا حتى يجد الدليل يخالفه}

Syariah umat sebelum kita juga adalah Syariah kita sehinggalah adalah dalil yang melarang perlaksanaannya. ${ }^{37}$

Sahīh Muslim, no. hadis: 2944.

36 Ibn Hajr al-'Asqalān̄̄, Fatḥ al-Bārī, 10: 285.

37 Al-Qarāfī, al-Zakhirah, Sa'īd A'rab (tahqiq) (Bayrūt: Dār al-Gharb al-Islāmī, 1994), 4 : 378. 
Kaedah ini selari dengan pandangan bahawa tiada al-tasyabbuh dalam perkara yang disepakati oleh agama-agama Samawi. Ini bermakna al-tasyabbuh tidak berlaku pada perkara yang disepakati di antara agama Islam dan agama lain seperti Nasrani dan Yahudi. Ia tidak termasuk amalan agama budaya. Elemen persamaan termasuklah asas kepercayaan seperti kepercayaan kepada Allah, dan para Nabi, serta unsur-unsur akhlak yang mulia. Begitu juga dengan hukum-hukum dalam agama seperti mengebumikan mayat, asal hukum berpuasa 'Asyura dan sebagainya. Ini dibahaskan oleh para fuqaha di bawah tajuk 'syariat umat yang terdahulu' (Syar ' man qablana $).{ }^{38}$ Walau bagaimanapun, terdapat beberapa amalan kaum yang terdahulu ini yang disunatkan untuk umat Islam supaya mereka meninggalkannya atau melaksanakannya dalam keadaan yang berbeza.

Antara dalil yang menyokong kaedah ini adalah hadis yang diriwayatkan oleh Ibn 'Abbās r.a., beliau bahawa ketika Rasulullah SAW sampai di Madinah, Baginda mendapati golongan Yahudi berpuasa pada hari 'Asyura. Nabi SAW lalu bersabda: ${ }^{39}$

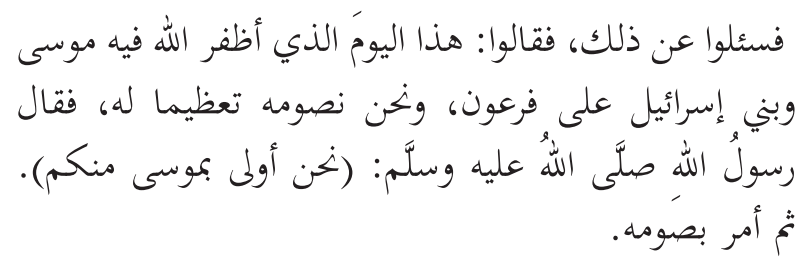

Baginda bertanya mereka: Hari apakah yang kamu berpuasa padanya ini?" Mereka menjawab: "Hari ini adalah hari Allah SWT menyelamatkan Musa dan Bani Israil dari Fir 'aun. Maka kami berpuasa sebagai membesarkan hari ini." Rasulullah SAW lalu bersabda: "Kita lebih berhak dan lebih utama untuk (meraikan) Musa daripada mereka. Kemudian Baginda memerintahkan untuk berpuasa.

38 Badr al-Dīn bin Muhammad Bahādir al-Zarkasȳ̄, al-Baḥr al-Muḥ̄t (Qāhirah: Dār al-Kutub, 1994), 8 : 41.

39 Al-Bukhārī, Saḥiḥ al-Bukhārì, no. hadis: 3943. 
Antara beberapa hukum fiqh yang termasuk di bawah kategori kaedah ini adalah seperti:

a) Walaupun asal kepada amalan puasa 'Asyura daripada ajaran agama Yahudi, namun ia tidak dianggap sebagai salah satu perbuatan al-tasyabbuh kerana Rasulullah SAW sendiri yang melaksanakannya.

b) Sebahagian fuqaha menjawab dakwaan yang menyatakan dilarang untuk imam di dalam solat untuk berdiri di dalam minbar masjid kerana didakwa menyerupai perbuatan ahli kitab. Mereka menyatakan bahawa perkara tersebut tidak dianggap sebagai al-tasyabbuh. ${ }^{40}$

Dalam konteks Malaysia, kaedah ini tidak sesuai diaplikasikan kerana ianya lebih relevan bagi isu-isu yang melibatkan agama Samawi sahaja seperti Yahudi dan Kristian, dan tidak sesuai bagi agama budaya. Ini kerana agama budaya tidak berasaskan wahyu dan hanya bersandarkan kepada akal serta nafsu manusia semata-mata. Meskipun dalam agama budaya, terdapat juga nilai positif seperti tolak ansur, tolong menolong, berbuat baik dan seumpamanya, namun tidak timbul isu al-tasyabbuh kerana nilai tersebut adalah sebahagian daripada ajaran Islam.



Setiap sebab yang membawa kepada mafsadah adalah dilarang jika tidak terdapat sebarang maslahah yang rajih. ${ }^{41}$

Setiap sebab yang boleh mendorong kepada fasad, adalah dilarang sekiranya tiada kemaslahatan yang lebih utama (mașlahah al-rājihah). Ini bermaksud bahawa setiap yang dilarang atas dasar pencegahan (sadd al-dharī'ah) yang tidak diharamkan,

40 Ibn Hummām, Syarh Fath al-Qādir, 'Abd al-Razzāq Ghālib alMahd̄̄ (tahqiq) (Bayrūt: Dār al-Kitāb al-'Ilmiyyah, t. t.), 1 : 413.

41 Muhammad Ibn 'Abd al-Raḥmān al-Sa'dān, "Qawā'id wa Dawābit Fiqh ‘inda Ibn Qudāmah” (Tesis Ph.D, Jāmi'ah Umm al-Qurā, 1420), 303. 
diharuskan untuk dilaksanakan apabila didasarkan kepada kemaslahatan yang perlu diutamakan (mașlaḥah al-räjiḥah). Oleh yang demikian sebarang perbuatan, perkataan, dan keadaan yang menyerupai orang bukan Islam yang dilarang oleh Syarak atas dasar pencegahan ini akan terangkat hukum haram padanya apabila wujudnya maslahah yang kuat.

Dalil yang menyokong kaedah ini melibatkan hasil penelitian secara induktif (istiqra ') terhadap perkara-perkara yang dilarang atas dasar pencegahan, dan kemudiannya diharuskan atas dasar mașlaḥah al-räjihah. Ibn Taymiyyah sendiri menegaskan hal ini dengan menyatakan:

Jika seorang Muslim berada di negara yang memerangi Islam (Dār al-Harb), atau negara kuffar yang tidak memerangi Islam, mereka itu tidak diperintahkan untuk berbeza dengan masyarakat kafir tersebut dari segi penampilan zahir, disebabkan terdapatnya kemudaratan pada perkara tersebut, malah disunatkan kepada paralelaki, atau diwajibkan bagi mereka untuk sesekali menyertai mereka (orang kafir) pada penampilan zahir, jika padanya terdapat maslahah pada agama: seperti berdakwah kepada mereka memahami agama Islam, untuk mengetahui keburukan amalan mereka dan memaklumkannya kepada orang Islam, atau mempertahankan orang Islam daripada kemudaratan oleh mereka, dan yang sepertinya daripada tujuan yang baik (maqāșid alhasanah) ${ }^{42}$

Hukum fiqh berkaitan kaedah ini adalah:

a) Di dalam Fatawa al-Hindiyyah menyatakan bahawa: Dimakruhkan untuk menanam pokok di persekitaran masjid kerana ia menyerupai gereja-gereja. Ia juga menyempitkan ruang untuk bersolat. Namun ia dibenarkan jika perbuatan tersebut memberi manfaat kepada masjid. Ini kerana jika tanah masjid mudah dialirkan oleh air dan struktur yang tidak kukuh, maka dibolehkan menanam pokok untuk

42 Ibn Taymiyyah, Iqtiḍā' al-Șirāṭ al-Mustaqīm, 1 : 418. 
mengurangkan kadar pengaliran tanah tersebut. ${ }^{43}$

b) Solat pada waktu-waktu yang dilarang adalah ditegah sama sekali kerana menyerupai perbuatan sujud orang bukan Islam kepada matahari. Walau bagaimanapun perbuatan ini dibenarkan atas dasar mașlahah al-räjihah seperti untuk menqada'kan solat, solat jenazah, dan sebab-sebab lain yang dibenarkan.

Dalam konteks Malaysia, kaedah ini dapat diaplikasikan dalam isu penyertaan pemimpin negara dalam sambutan perayaan di rumah ibadat orang bukan Islam. Pengecualian khusus ini adalah berdasarkan mașlahah al-räjiḩah yang mana kehadiran tersebut boleh menyumbang kepada keharmonian kaum dan perpaduan negara. Selaras dengan itu, larangan tersebut masih lagi terpakai kepada orang Islam selain jawatan pemimpin negara, walaupun kehadiran mereka hanya bertujuan meraih sokongan politik. Kehadiran mereka boleh menimbulkan al-tasyabbuh.

vi.

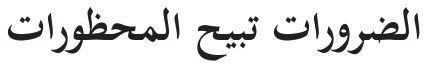

Keadaan darurah mengharuskan perkara yang dilarang ${ }^{44}$

Kaedah ini selaras dengan pandangan tiada al-tasyabbuh dalam keadaan darurat. Misalnya bagi umat Islam minoriti yang tinggal di negara bukan Islam, dalam keadaan nyawa dan maruah yang terancam, mereka dibenarkan untuk menyerupai pakaian atau meniru cara hidup orang bukan Islam demi keselamatan nyawa (hifz al-din wa al-nafs) mereka. Penyerupaan ini tidak dianggap sebagai al-tasyabbuh yang dilarang.

43 Syaykh Niẓām, al-Fatāwā al-Hindiyyah (Bayrūt: Dār al-Kitāb al'Ilmiyyah, 2001), 1 : 110.

44 Al-Nadwī, al-Qawā 'id al-Fiqhiyyah, 270. 


\section{vii. الإعانة على فعل الظلم من فعل حرام}

Pertolongan ke atas sesuatu perbuatan yang zalim adalah perbuatan yang haram ${ }^{45}$

Kaedah ini merujuk kepada setiap perkara yang dilaksanakan oleh Muslim berbentuk penyerupaan terhadap orang bukan Islam, atau yang membawa kepada penyerupaan tersebut, maka tidak wajar diberikan sebarang dukungan kepadanya. Ia bermaksud setiap perbuatan orang Islam yang merupakan al-tasyabbuh yang sebenar atau yang nampak secara zahir, dikategorikan sebagai perbuatan yang haram, dan diharamkan juga sebarang bentuk pertolongan atau sokongan terhadap perbuatan tersebut. Ini kerana sebarang pertolongan terhadap perbuatan tersebut menandakan keredhaan terhadapnya, sedangkan keredhaan terhadap sesuatu perbuatan seakan melaksanakan perbuatan tersebut sendiri. Hukumnya adalah haram. Termasuk juga dalam hal ini pertolongan terhadap sebarang perbuatan yang dapat membawa kepada perbuatan altasyabbuh itu sendiri. Ini menunjukkan bahawa ajaran Islam melarang Muslim untuk mendekati perbuatan al-tasyabbuh.

Kaedah ini bersandarkan kepada dalil yang berbentuk umum. Antaranya ialah surah al-Mā'idah, ayat 2:



"Dan bertolong-tolonglah kamu atas kebaikan dan taqwa, dan janganlah kamu bertolong-tolong atas perkara dosa dan permusuhan."

Ayat ini menyatakan prinsip yang asasi dalam ajaran agama Islam, iaitu galakan saling tolong-menolong dalam perkara kebaikan dan tidak berkompromi dengan maksiat dan dosa. Misalnya, larangan menjadi penulis dalam kontrak yang melibatkan unsur riba dan larangan menghidang arak kepada peminumnya.

45 'Ābid bin 'Abd Allāh al-Thabitī, Qawā'id wa Dawābiṭ Fiqh 'inda Syaykh al-Islām Ibn Taymiyyah (Sa'ūdī: Dār Ibn al-Jawzī, 2008), 364. 
Oleh kerana al-tasyabbuh juga merupakan perbuatan mungkar yang dilarang, jadi sebarang pertolongan terhadap perkara tersebut turut sama dilarang.

Hukum fiqh berkaitan kaedah ini adalah seperti berikut:

a) Tidak wajib untuk menghadiri sebarang jemputan bagi majlis yang diadakan oleh orang bukan Islam yang mempunyai sebarang unsur al-tasyabbuh. Dalam konteks Malaysia, ia termasuklah larangan penyertaan orang Islam dalam sambutan perayaan di gereja, kuil, tokong atau rumah ibadat khusus agama tertentu.

b) Diharamkan kepada Muslim untuk memperniagakan perkara yang dapat membantu masyarakat Islam untuk menyerupai orang kafir dalam perayaan mereka. Dalam konteks Malaysia termasuklah berniaga lilin untuk perarakan tertentu dan menjual coklat serta bunga di hari Valentine kepada pasangan kekasih. Ini kerana kemudahan ini akan mendorong orang Islam untuk terlibat dalam amalan tersebut.

\section{viii. تصرف الإمام على الرعية منوط بالمصلحة}

Tindakan pemerintah terhadap rakyat berdasarkan maslahah.

Kaedah ini dapat diaplikasi dalam amalan al-tasyabbuh yang bertentang dengan ajaran Islam, yang mana terdapat peruntukan hukuman oleh Syarak atau digubal Pemerintah. Kebanyakan nas Syarak yang menyatakan mengenai larangan menyerupai orang bukan Islam adalah berbentuk umum dan tidak menyatakan sebarang hukuman yang khusus ke atas perbuatan tersebut. Selaras dengan itu, bentuk hukuman yang ditetapkan oleh Syarak, berhubung dengan perbuatan-perbuatan al-tasyabbuh hakikatnya dihukum atas dasar perbuatan tersebut sendiri adalah haram dan bukan kerana ia adalah al-tasyabbuh. Ini adalah seperti hukuman sebat kepada peminum arak yang walaupun ianya perbuatan orang bukan Islam, namun dikenakan hukuman atas kapasitinya sebagai perbuatan haram dan bukannya sebagai perbuatan al-tasyabbuh. 
Bagi perbuatan al-tasyabbuh yang disertai niat yang jelas untuk menyerupai orang kafir, maka seseorang akan jatuh menjadi murtad sekiranya memenuhi syarat-syarat hukum tersebut. Oleh itu, dia akan menghadapi kesemua prosedur hukuman murtad seperti peluang untuk bertaubat (istitāa $b)^{46}$ dan sebagainya.

Manakala bagi perbuatan al-tasyabbuh yang tidak disertakan sebarang niat, ia dianggap sebagai haram atas dasar sadd aldhari'ah dan hukuman yang dikenakan padanya melibatkan dua bentuk:

a) Sekiranya perbuatan tersebut termasuk dalam kategori larangan yang telah ditetapkan hukuman terhadapnya oleh nas-nas Syarak, maka pelaku al-tasyabbuh perlu menghadapi hukuman berkaitan.

b) Sekiranya tidak terdapat hukuman yang ditentukan oleh Syarak, maka dikenakan hukuman ta'zìr dengan menimbangkan aspek kemaslahatannya (mașlahah). Hukuman ta'zìr bagi perbuatan ini pula terbahagi kepada dua keadaan iaitu:

i) Dharī'ah yang bersifat umum yang menuntut peranan setiap individu Muslim untuk memikul tanggungjawab bagi mencegahnya. Ini seperti peranan ketua keluarga untuk memastikan ahli keluarganya tidak terjebak ke dalam perbuatan al-tasyabbuh. Hukuman yang maksimum bagi kategori dharī'ah ini adalah pukulan atau sebatan ringan yang tidak sampai kepada hukuman berat.

ii) Dhar'`'ah yang bersifat khusus yang menuntut peranan pihak pemerintah untuk melaksanakannya. Dalam kategori ini pemerintah dapat melaksanakan setiap hukuman yang dirasakan sesuai dengan sebarang perbuatan al-tasyabbuh. Ini termasuk hukuman sebatan, tahanan, buang negeri dan sebagainya. ${ }^{47}$

46 Țāha Jābir al-'Alwān̄i, Lā Ikrāha fì al-Dīn: Isykāliyyah al-Riddah wa al-Murtadd̄̄n min Sadr al-Islām ilā al-Yawm (Qāhirah: IIIT \& Maktabah al-Masyrūq al-Dawliyyah, 2006), 189.

47 Muḥammad Hisyām al-Burhān̄̄, "Sadd al-Dharā' 'i ' fì Syarī'ah alIslāmiyyah” (Disertasi Master, Dār al-'Ulūm, Universiti Qāhirah, Mișr, 1985). 
Dalil-dalil Syarak yang menyokong kaedah ini ialah nas-nas yang menyentuh mengenai sadd al-dhari' $a h$. Antaranya adalah ayat al-Quran, surah al-An'ām, ayat 108 yang menyatakan mengenai larangan mencela sembahan orang bukan Islam atas dasar pencegahan daripada tindakan mereka mencela Allah SWT iaitu:

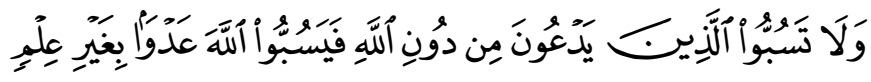

"Janganlah kamu mencela orang yang menyeru kepada selain Allah, maka mereka akan mencela Allah dengan permusuhan tanpa berdasarkan ilmu."

Al-Dhahabī menegaskan mengenai perbuatan menyerupai orang bukan Islam dalam isu perayaan hendaklah ditangani oleh pihak pemerintah. Beliau menyatakan:

"Demi Allah, tidak diberi keluasan kepada masyarakat awam (wālì al-sukūt) untuk mencegah perkara ini, bahkan diwajibkan ke atas setiap muhtasib bagi sesebuah negara untuk mencegah perkara ini dengan sebarang kaedah yang sesuai. Ini kerana dengan mengekalkan keadaan ini akan lebih mendorong penganut Kristian untuk menzahirkan agama mereka." ${ }^{48}$

Hukum-hukum fiqh bagi kaedah ini adalah seperti orang yang mengenakan pakaian orang bukan Islam yang khusus bagi mereka, seperti pakaian sami, paderi, Santa Clause yang menjadi identiti agama bukan Islam. Perbuatan ini wajib ditegah daripada melakukannya. Jika individu tersebut enggan menanggalkannya, maka sebarang hukuman boleh dikenakan ke atasnya sehingga dia meninggalkan perbuatan tersebut.

Dalam konteks Malaysia, kaedah ini boleh diaplikasi terhadap orang Islam yang memakai simbol agama bukan Islam seperti salib, simbol syaitan (klenik, segi enam dan sebagainya) dan pakaian penyembah syaitan (black metal). Dalam hal ini, pemerintah boleh

48 Al-Dhahabī, Tasybīh al-Khașīṣ, 197. 
mengenakan hukuman yang sesuai dan setimpal kerana ia boleh merosakkan akidah umat Islam.

\section{PENUTUP}

Fenomena al-tasyabbuh makin menular dalam masyarakat Islam di Malaysia kini. Ianya adalah kesan interaksi dengan budaya asing di samping lanjutan proses interaksi dengan budaya masyarakat setempat. Namun, Islam sebagai agama yang syumul telah meletakkan asas yang kukuh dalam menangani senario ini. Kaedah fiqh yang dibangunkan oleh ulama silam dapat diaplikasikan sama ada yang menyentuh segala aspek perbuatan al-tasyabbuh dari sudut niat pelaku, skop perlakuan, aspek pengecualian sehinggalah kepada aspek hukuman ke atas pelakunya.

Sehubungan dengan itu, masyarakat Islam di Malaysia perlu berhati-hati dalam mengamalkan amalan seharian. Persoalan agama dan adat orang bukan Islam perlu dititikberatkan kerana kedua-duanya berasaskan kepercayaan masyarakat, apatah lagi bentuk keagamaan orang bukan Islam di Malaysia didominasi oleh agama budaya (wad ' $\vec{\imath}$ ). Ini kerana ditakuti berlaku elemen al-tasyabbuh yang dilarang tanpa disedari disebabkan sikap mengambil ringan terhadap perkara tersebut. Keadaan ini boleh menimbulkan implikasi hukum. Justeru, kaedah fiqh ini bersifat praktikal untuk diaplikasikan khususnya dalam menilai realiti amalan masyarakat Islam di Malaysia.

\section{BIBLIOGRAFI}

'Abd bin Ḥumayd. Al-Muntakhab min Musnad. Muștafā al-'Adwī (tahqiq). Makkah: Maktabah Ibn Hajr, 1408H.

Aḥmad Fāris. Mu jam Maqāyìs al-Lughah. 'Abd al- Salām Hārūn (tahqiq). Bayrūt: Dār al-Jayl, 1411H.

Al-“Alwānī, Țahā Jābir. Là Ikrāh fì al-Dīn: Isykāliyyah al-Riddah wa al-Murtaddīn min Șadr al-Islām ilā al-Yawm. Qāhirah: IIIT \& Maktabah al-Masyrūq al-Dawliyyah, 2006. 
Al-'Asqalān̄̄, Ibn Hajar. Fatḥ al-Bārī bi Syarh Șaḥịh al-Bukhārī. Qāhirah: Maṭba'ah al-Salafiyyah, 1960.

Asyraf bin 'Abd al-Hamīd Barqa'an. "Mazāhir al-Tasyabbuh fì al-“Așr al-Ḥadīth wa Atharuhā 'ala al-Muslimīn”. Disertasi Master, Universiti Umm al-Qurā, 1417H.

Al-Bahūtī, Manșūr b. Yūnus b. Idrīs. Kasysyāf al-Qinā' 'an Matn al-Iqnā'. Bayrūt: 'Alam al-Kutub, t. t.

Al-Burhān̄̄, Muḥammad Hisyām. "Sadd al-Dharā'i ' fì Syarī'ah al-Islämiyyah.” Disertasi Master, Dār al-'Ulum, Universiti Qāhirah, Mișr, 1985.

Al-Burnū, Muhammad Șidq̄i Ibn Aḥmad. Mawsū'ah al-Qawā 'id al-Fiqhiyyah: Jam 'wa Tartīb wa Bayān, Bayrūt: Mu'assasah al-Risālah, t. t.

Al-Dhahabī. Tasybīh al-Khașiș li Ahl al-Khamīs fì Radd alTasyabbuh bi al-Musyrikin. Muhammad Hassan Ibn Muḥammad Hassan Ismā‘̄il (tahqiq). Bayrūt: Dār al-Kitāb al-Istāmī, 2002.

Ibn 'Ābidīn. Hāāsyiyah Ibn 'Ābidīn. 'Ādil 'Abd al-Mawjūd (tahqiq). Bayrūt: Dār al-Kutub al-'Ilmiyyah, 1415H.

Ibn Hummām. Syarh Fatḥ al-Qādir. 'Abd al-Razzāq Ghālib alMahdī, Bayrūt: Dār al-Kitāb al-'Ilmiyyah, t. t.

Ibn Manzūr. Lisān al-Arab. Bayrūt: Dār Ihyyā’ al-Turāth al-'Arabī, 1999.

Ibn Taymiyyah. Iqtiḍa' al-Ṣirāt al-Mustaqīm. Nāṣir bin 'Abd alKarīm (tahqiq). Riyāḍ: Maktabah al-Rusyd, t. t.

Imām Mālik. Al-Mudawwanah. Șahnūn \& Ibn al-Qāsim (Syarḥ). Qāhirah: Maṭba'ah al-Sa'ādah, t. t.

Al-Jawziyyah, Ibn al-Qayyim. Ahkām Ahl al-Dhimmah. Șubḥ̄ Șāliḥ (tahqiq). Bayrūt: Dār al-'Ilm al-Malāyīn, 1983.

Al-Jawziyyah, Ibn al-Qayyim. I'lām al-Muwaqqi 'ìn 'an Rabb al'Ālamīn. Țāhā 'Abd al-Ra'ūf (tahqiq). Bayrūt: Dār al-'Ilm 
al-Malāyīn, 1983.

Al-Kāsān̄̄. Badā'i' al-Șanā'i' fì Tartīb al-Syarā'i'. 'Alī Muḥammad Ma'wid \& 'Ādil Aḥmad (tahqiq). Bayrūt: Dār al-Kutub al-'Ilmiyyah, t. t.

Al-Luwayḥiq, Jamīl Habīb. Al-Tasyabbuh al-Manhī 'anhu fì alFiqh al-Islāmī. Makkah: Jāmi'ah Umm al-Qurā \& Wizārah Ta'līm ‘Ālī, $1417 \mathrm{H}$.

Mohd Anuar Ramli \& Mohammad Aizat Jamaludin. "Uruf Majmuk: Konsep Dan Amalannya Dalam Masyarakat Majmuk Di Malaysia." Jurnal Fiqh, No. 8 (2011): 45-64.

Al-Mubārakfūrī, Muhammad 'Abd al-Raḥmān b. 'Abd al-Rahīm. Tuhfah al-Ahwāadhī. Bayrūt: Dār al-Kutub al-'Ilmiyyah, t.t.

Muhammad Bakr Ismā'īl. Al-Qawāid al-Fiqhiyyah: Bayn alAṣālah wa al-Tawjīh. Qāhirah: Dār al-Manār, 1997.

Muḥammad Ibn Abī Syaybah. Al-Mușannif. Mukhtār al-Nadwī (tahqiq). Hind: al-Dār al-Salafiyyah, t. t.

Al-Qusyayrī, Muslim al-Ḥajjāj. Șaḥ̄h Muslim. Bayrūt: Dār Iḥyā’ al-Kitāb al-'Arabiyyah, t. t.

Al-Nadwī, 'Alī Aḥmad. Al-Qawā 'id al-Fiqhiyyah. Damsyiq: Dār al-Qalam, c. 2, 1991.

Al-Qarāfî. al-Zakhīrah. Bayrūt: Dār al-Gharb al-Islāmī, 1994.

Al-Qurțubī, Muhammad b. Aḥmad. Tafsìr al-Qurțubī. Qāhirah: Dār al-Sya'b, 1372.

Rasyīd Riḍā. Fatāwā al-Imām Muhammad Rasyīd Riḍā. Șalāḥ alDīn Munjid (tahqiq). Bayrūt: Dār Kitāb al-Jadīd, 1426H.

Ṣāliḥ Fawzān. Aqīdah Tawhìd. Riyāḍ: Dār al-Qāsim, t. t.

Al-Sa'dān, Muḥammad Ibn 'Abd al-Raḥmān. "Qawā'id wa Dawābit Fiqh 'Inda Ibn Qudāmah”. Tesis Ph.D, Jāmi'ah Umm al-Qurā, $1420 \mathrm{H}$. 
Syaykh Nizāam. Al-Fatāwā al-Hindiyyah. Bayrūt: Dār al-Kitāb al'Ilmiyyah, 2001.

Al-Thābitî, 'Ābid bin 'Abd Allāh. Qawā'id wa Dawābit Fiqh 'inda Syaykh al-Islām Ibn Taymiyyah. Sa'ūdī: Dār Ibn alJawzī, 2008.

Al-Tuwayjirīi, 'Abd Allāh 'Abd al-'Azīz. Al-Bida' al-Hawliyyah, (terj.) Munirul Abidin. Jakarta: Darul Falah, 2000.

Al-Zarkasyī, Syams al-Dīn. Al-Mabsūṭ. Bayrūt: Dār al-Ma'rifah, $1331 \mathrm{H}$.

Al-Zarkasyī, Badr al-Dīn bin Muḥammad Bahādir. Al-Baḥr alMuhịṭ. Qāhirah: Dār al-Kutub, 1994. 
Jurnal Fiqh, No. 11 (2014) 1-28 